DOI: https://doi.org/10.35387/ucj.2(4).2021.21-25

OLENA ANISHCHENKO

\title{
EDUCATION OF ELDERLY PEOPLE AS AN EDUCATIONAL TREND OF THIRD MILLENNIUM
}

\begin{abstract}
The publication is devoted to the analysis of some features of elderly education development. There is a substantiation of the urgency of the raised problem. Emphasis is placed on the fact that the education of elderly people is an indicator of the development level of cultural, moral, scientific and technical potential of the country. The focus is on the essential aspects of hierargoics as a science. The need to develop a new perception philosophy of population aging and strategies to ensure old age in the life cycle of each individual is emphasized. The necessity of implementation of the complex state policy on education of elderly people, development and implementation of multi-vector programs for the outlined category of adult population is substantiated. It is emphasized that universities of the third age function as social projects in all regions of Ukraine. In the article highlighted the development of the state target program "Universities of the third age: it is never too late to study"; creation of the third age virtual universities (online universities); scientific substantiation of organizational and pedagogical conditions of creation and functioning of the third age universities; strengthening intersectoral / interagency cooperation and expanding networking in the world of elderly at the local and national levels. It was emphasized that institutions for the education of older adults should promote the development of their social activity, overcome isolation, loneliness and provide comprehensive socio-cultural adaptation and rehabilitation. Special attention is paid to the issue of pedagogical staff training for the teaching of the elderly. The expediency of interdisciplinary research on the theory and practice of senior adult education is substantiated. It is determined that a perspective area of further research is the problem of scientific and methodological support for the elderly education.
\end{abstract}

Key words: adult education, elderly education; third age; active longevity; andragogy; heroics.

\section{ОСВІТА ЛЮДЕЙ СТАРШОГО ВІКУ - ОСВІТНІЙ ТРЕНД ТРЕТЬОГО ТИСЯЧОЛІТТЯ}

Анотація. Публікація присвячена аналізу окремих особливостей розвитку освіти людей третього віку. Здійснено обгрунтування актуальності порушеної проблеми. Акцентовано увагу на тому, що освіта літніх громадян є показником рівня розвитку культурного, морального, наукового, технічного потенціалу країни. Зосереджено увагу на сутнісних аспектах герагогіки як науки. Підкреслюно необхідність розробки нової філософії сприйняття старіння населення та стратегії забезпечення старості в життєвому циклі кожної особистості. Обгрунтовано необхідність здійснення комплексної державної політики щодо освіти людей старшого віку, розроблення та впровадження різновекторних програм для окресленої категорії дорослого населення. Наголошено, що університети третього віку як проєкти соціального спрямування функціонують в усіх регіонах України. Доведено доцільність: розроблення державної цільової програми «Університети третього віку: навчатися ніколи не пізно»; створення віртуальних університетів третього віку (онлайн університетів); наукового обгрунтування організаційно-педагогічних умов створення й функціонування університетів третього віку; посилення міжсекторної / міжвідомчої взаємодії та розширення мережевої взаємодії у сфері світи дорослих старшого віку на місцевому й національному рівнях. Наголошено, що заклади для навчання дорослих старшого віку мають сприяти розвитку їх соціальної активності, подоланню ізольованості, самотності й передбачати комплексну соціально-культурну адаптацію та реабілітацію. Окрему увагу приділено питанню підготовки педагогічного персоналу для навчання осіб старшого віку. Обгрунтовано доцільність міждисциплінарних досліджень з теорії і практики освіти старших дорослих. Визначено, що перспективним напрямом подальших досліджень є проблема науково-методичного забезпечення освіти людей похилого віку.

Ключові слова: освіта дорослих: освіта людей третього віку; третій вік; активне довголіття; андрагогіка; герагогіка.

Introduction. Socio-economic, demographic, technical and technological transformations in the state determine the development of the learning society. In such society, it is assumed that a person throughout his/her life has the desire and ability to learn not only out of neces- sity (eg, professional), but also based on own civic position, the inner need to acquire new knowledge, skills and abilities. Members of the learning society use the opportunities of formal, non-formal and informal education, and the results of education obtained in all formats 
of learning are taken into account and complementary. In addition to lifelong learning, a learning society, inherent: promoting the development of knowledge diversity as a value, adherence to the principle of equal opportunities, universal access of all to knowledge and information, etc. (Pryima, 2021).

In the conditions of learning society development, the problems of human activity, its conscious participation in socio-cultural life, readiness for self-realization and constant selfimprovement become especially relevant. At the same time, the majority of countries around the world are at risk of global aging. Experts have been sounding the alarm for a long time, as demographic problems could lead to economic ones in the near future. According to scientists, the number of elderly people in the world is growing steadily and will continue to grow. For example, according to Gender Silver Economy for Local Community Development (2021), as of January 2020, there were 11.3 million retirees in Ukraine.

Thus, the aging of the population is becoming a pressing problem today and necessitates the rational planning of post-professional and post-family phases of human life in order to solve it more successfully. There is no doubt that in modern conditions education is a means of social adaptation to the third age. Its indicates the need for a comprehensive state policy on education of the elderly, development and implementation of multi-vector programs for this category of adults.

The aim of the study is to analyze the problem of elderly education in the context of active longevity practices.

Theoretical basis and research methods. Interdisciplinary research in the field of different categories of adult's education was carried out by S. Arkhipova, O. Banit, O. Voliarska, L. Lukianova, etc. Various aspects of the elderly education development in Ukraine are covered in the scientific works of Ukrainian researchers (A. Bogutska, M. Bukach, M. Zhytynska, N. Kabachenko, V. Kipen, S. Nestuliia, V. Robak, T. Skoryk, A. Khaletska, etc.). Peculiarities of teaching older adults in foreign countries are described in the scientific work of E. Bohiv, A. Bogutska, V. Polishchuk, O. Pryshliak, I. Sagun, N. Chagrak, etc. The urgency of the problem, its insufficient development, the need to justify the best ways to solve it led to the choice of our publication theme.

In the process of scientific research we used interpretive and theoretical research methods, including: analysis and synthesis (helped to identify the essence of the research problem, substantiate recommendations for older people education development); method of terminological analysis (helped to determine the categorical status of the studied concepts and terms in the system of pedagogical definitions); methods of abstraction, formalization, generalization (to clarify the key concepts of the study, to formulate conclusions, to outline areas for further research on the problem, etc.).

Results. In Ukraine, at the state level declared:

- building a flexible system of adult education, ensuring the development of non-formal education and encouraging lifelong learning;

- creating conditions for comprehensive human development throughout life, expanding opportunities for self-realization of the individual, his/her civic activity for the formation of the citizen's cohesive community, capable of active creative participation in harmonious, balanced and sustainable development (Decision of the National Security and Defense Council of Ukraine, 2021);

- popularization in society of the idea of mutual responsibility of generations, formation of a positive attitude to the elderly and senile age, conducting informational and educational work aimed at explaining the objective nature of population aging, related challenges and potential opportunities and the need to adapt a demographic change (The order of the Cabinet of Ministers of Ukraine, 2018).

According to N. Chagrak (2019), the main provisions of the aging theories and old age determine the feasibility of analyzing the life of older people in the context of human resources problems and human capital. It is the analysis of aging and old age as a promising resource, based on the ideas of activity theories and lifelong development of the individual, allows justifying the need for education of the elderly, research in the field of educational gerontology.

The education of senior citizens is an indicator of the cultural, moral, scientific, technical potential level development of the country. In particular, the Concept of Adult Education in 
Ukraine (developed by prof. L. Lukianova) emphasizes the need to develop a new philosophy of population aging perception and strategies for ensuring old age in the life cycle of each individual (Lukianova, 2011, p. 10). The need for education of older adults has actualized the development of the third age pedagogy (pedagogy of aging and old age / pedagogy of old age / gerontogogy / gerontopedagogy / heragogy) (geraos - old, ago - to lead, show the way). Heragogy is a field of social practice, the Andragogy chapter engaged in the study of methods, patterns of education, training, retraining, features of elderly socialization (synonyms: retirement, elderly, third age people, golden age, senior adults, etc.).

At the present stage of science development, the elderly education (geronto-education) is considered as a component of lifelong learning, a form of socio-cultural self-realization of the older people personality, a social phenomenon. Its development is due to globalization and integration processes, demographic factors, a set of internal and external political, socioeconomic and educational needs of adults and society (Sagun, 2011, p. 12). This science is designed to promote the development of the elderly in the post-professional period, support and development of their physical, psychological and social abilities, improve social status, quality of older adult's life, and prevent the old age devaluation. The contingent of gerontoeducation consists of working age people (55 years and older) who are entering or have already entered the post-professional phase of life, combine educational activities with personal participation in various spheres of life and express a desire to constantly improve their general, professional and cultural level.

It should be noted that active longevity centers / clubs, universities of the third age (UTA) - non-formal education institutions for older adults, operating independently or on the basis of territorial centers of social services, formal and non-formal education institutions, culture and public institutions, etc. have become widespread in the national educational space (Anishchenko, 2021). UTAs are educational institutions of various forms of ownership (state, nonstate). Their founders can be public organizations and charitable foundations in partnership with foreign sponsors, financial institutions, etc. (Skoryk, 2015).
Since 2011, in accordance with the order of the Ministry of Social Policy of Ukraine «On the introduction of social and pedagogical services «University of the Third Age» (2011), the provision of social and pedagogical services «University of the Third Age» is provided by structural units of territorial centers of social services. These institutions represent one of the modern integration models of the elderly into modern society by intensifying their activities, which improves the quality of life, promotes the introduction of active longevity ideas. The purpose of UTA is to promote intellectual, mental, social and physical activity of the older age group through the diverse people development in retirement age, reintegration of the elderly into active life, popularization of educational initiatives in adult education, helping older adults to adapt to modern living conditions, forming the principles of a healthy lifestyle in old age (Anishchenko, 2013).

Today, Universities of the Third Age operate in all regions of Ukraine as social projects aimed at implementing the principles of lifelong learning. The structure of training programs for the elderly depends on national and regional conditions, staffing, funding, etc. Among the most common faculties of UTA can be distinguished those that have linguistic, psychological, health, information and communication, legal, economic, artistic, direction, and so on. Not only pedagogical staff in the field of adult education, but also volunteers - students of free educational institutions, teachers, doctors, social workers, representatives of NGOs, etc. are involved in conducting training sessions, organizing excursions, trips, sports and recreation, group work, etc.

It is important that special seminars, courses for the elderly, clubs, centers of education and training for older adults (based on free educational institutions, libraries, etc.) have also become widespread in world educational practice. The development of geronto-education is facilitated by interest groups, aid and mutual aid groups, public associations, societies, including religious organizations. There are mobile Internet cafes, lecture halls, weekend seminars, etc. In foreign practice, the spread of senior adult education is promoted by associations, public organizations, foundations and corporations (American Council on Education, 2007, p. 2, 23). 
The results of our scientific research make it possible to substantiate prognostic recommendations for the adult education development in Ukraine, in particular:

1. Development of the state target program «Universities of the Third Age: it is never late to study», which will aim to help improve the implementation of state policy in support of vulnerable adults, living standards and quality of life of the elderly; creating conditions for the adaptation of older people in society, prolonging active longevity, strengthening their health, etc. by involving citizens in educational initiatives of non-formal education institutions; improving the quality and accessibility of educational services for older adults.

2. Creation of virtual Universities of the Third Age (online universities) on the basis of institutions of higher and postgraduate education, centers of social services, libraries, etc. Such institutions should be entrusted with: overcoming information inequality and active involvement of different people and, in particular, older age, in active social, socio-cultural life through the use of information and communication technologies; formation and development of information culture of retirement age people as a component of lifelong learning culture; promoting the creation a system of distance education for retirement age people, aimed at providing quality and affordable educational services to older adults as one of the most vulnerable categories of the adult population. The creation and further expansion of the network of such institutions should become one of the priority components of the action plan for the implementation in Ukraine of the Strategy of State Policy on Healthy and Active Longevity for the period up to 2022.

3. Scientific substantiation of organizational and pedagogical conditions of creation and functioning of Universities of the Third Age as set of the factors providing regulation, interaction of objects, the phenomena for achievement of the set purpose and reflect functional dependence of essential components of the pedagogical phenomenon on a complex of objects (things, their states, processes, interactions) in various manifestations. Organizational conditions include support for the possibility and support of the implementation of pedagogical conditions (development of regulatory and le- gal support; monitoring of cultural and educational needs, providing scientific and methodological, psychological and pedagogical, informational support of senior adult's education).

4. Strengthening intersectoral / interagency cooperation and expanding networking in the field of older adults at the local and national levels as a basis for implementing adequate social policy by strengthening the capacity of UTA and coordinating efforts and cooperation with other formal and non-formal education institutions, research institutions, cultural institutions, public associations, businesses, government officials in expanding the range of services in the field of non-formal education for the elderly in the regions; establishing partnerships, supporting cross-sectoral platforms and dialogue platforms to discuss the development of non-formal adult education.

Finally, we note that the expansion of the educational services market for the elderly raises the issue of teacher's professional training to work with this category of adults. We are talking about heragogy specialists in the field of theory and practice of elderly education, in the field of education, management, counseling, as well as social, correctional, rehabilitation work among older adults. Competent heragogy specialist can be teachers, psychologists, gerontologists, social workers and other professionals who have special professional training, constantly improving the level of professional competence in teaching adults of the third age. The heragogy specialist must have a high level of interpersonal, psychological, pedagogical and organizational interaction with all categories of older adults, as well as thorough knowledge of medical gerontology and medicine, psychology, sociology, law, pedagogy, and others. The system formation of pedagogical and special subject knowledge, a high level of methods mastery, technologies, methods of pedagogical interaction with the elderly, the formation of appropriate ethical and social positions, attitudes, high responsibility for the results of their professional activities. Such specialists are primarily called not to transfer knowledge, but to support the activity of learners, they must have the ability to design professional self-development, self-realization with appropriate techniques of individuality within the profession, be ready for professional 
growth (Lukianova, Anishchenko, Sigaeva, Zinchenko, Banit, \& Doroshenko, 2013, p. 62). Unfortunately, the professional training of heragogy specialists in Ukraine is not carried out yet.

Conclusions. In our opinion, the development of adult education should be carried out on an interdisciplinary basis, based on the study and further implementation of achievements in andragogy, pedagogy, age psychology, geromedicine, gerosociology, educational and social gerontology, special heragogy, pedagogy and gerontology. The educational environment for the elderly in multifunctional socio-cultural institutions should be formed on the basis of social partnership of all interested subjects of pedagogical, socio-cultural activities. Such an environment should promote the development of social activity of the elderly, overcome isolation, loneliness and provide for comprehensive socio-cultural adaptation and rehabilitation. The problem of development and implementation of pedagogical technologies based on the principles of personality-oriented learning, ensuring independence for the elderly, realization of internal potential, availability of information, meeting the cultural and educational needs of older adults needs special attention of educators-practitioners and scientists.

A promising area of further research is the problem of scientific and methodological support for the older people education.

\section{ЛITEPATУPA}

American Council on Education. (2007). First report: Reinvesting in the third age: Older Adults and Higher Education. Washington: American council on education.

Anishchenko, O.V. (2013). Education of the elderly as a response to the challenges of the XXI century. Andragogical Herald: scientific electronic journal, 4, 33-38. URL: https://library.zu.edu.ua/doc/ andragogic_visnyk/Andragogichniy_visnyk_4.pdf\#page=33

Anishchenko, O.V. (2021). University of the Third Age. In V.G. Kremen (Ed.), Encyclopedia of Education (2nd ed.; p. 1039-1040). Kyiv: Urinkom Inter.

Chagrak, N.I. (2019). Theory and practice of the elderly education in USA (1962-2015). (PhD dissertation). Drahomanov National Pedagogical University, Kyiv.

Decision of the National Security and Defense Council of Ukraine: On Human Development Strategy. №225/2021. (2021). URL: https://www.president.gov.ua/documents/2252021-39073

Gender silver economy for local community development. (2021). URL: https://cutt.ly/HIiOmL0

Lukianova, L.B. (2011). The concept of adult education in Ukraine. Nizhyn: LLC Lysenko M.M.

Lukianova, L.B., Anishchenko, O.V., Sigaeva, L.E., Zinchenko, S.V., Banit, O.V., \& Doroshenko, N.I. (2013). Modern technologies of adult education: a guide. Kirovograd: Imex-LTD.

Order of the Ministry of Social Policy of Ukraine: On the implementation of the socio-pedagogical service «University of the Third Age». №326. (2011). URL: https://cutt.ly/pIi0R6b

Pryima, S.M. (2021). Learning society. In V.G. Kremen (Ed.), Encyclopedia of Education (2nd ed.; p. 991992). Kyiv: Urinkom Inter.

Sagun, I.G. (2011). Development of the third age people education in Germany (second half of XX - the beginning of XXI century). (PhD dissertation). Ivan Ziaziun Institute of Pedagogical Education and Adult Education of NAES of Ukraine,Kyiv.

Skoryk, T.V. (2015). Socio-pedagogical effect of the University of the Third Age. Young scientist, 2(17), 466-469. URL: http://ir.stu.cn.ua/handle/123456789/1862;jsessionid=A505B6BB4FE191F26865D1D81734D35B

The order of the Cabinet of Ministers of Ukraine: Strategy of state policy on healthy and active longevity of the population until 2022. №10-r. (2018). URL: https://cutt.ly/8Ii00K1

Олена Аніщенко, доктор педагогічних наук, професор, завідувач відділу андрагогіки Інституту педагогічної освіти і освіти дорослих імені Івана Зязюна НАПН України.

Olena Anishchenko, Doctor of Sciences in Pedagogy, Professor, the Head of the Department of Andragogy, Ivan Ziaziun Institute of Pedagogical Education and Adult Education of NAES of Ukraine.

E-mail: anishchenko olena@ukr.net ORCID ID 0000-0002-6145-2321 